\title{
The Relationship between the Academic Performances in Required Major Courses and the Core Courses Achievement of Food Science and Technology Students
}

\author{
N. Prapasuwannakul and K. Bussaban
}

\begin{abstract}
The purpose of this study is to measure the proportion of variation in the academic performance in required major courses form the subjects in core courses of Food Science and Technology students. Data were collected from a sample of 183 online reports of science students graduating from Food Science and Technology Program, Suan Sunandha Rajabhat University during the academic year of 2011-2017. Variables used to construct a regression model were grades of the subjects in core courses and average grades of the subjects in required major courses. The findings revealed that there is a positive significant strong linear relationship between the core courses achievement and the academic performance in required major courses. Organic chemistry, Physical chemistry, Analytical chemistry, Microbiology and Basic biology grades express their strong relationship with academic performance in required major courses. The highest of the proportion of variation in the academic performance is Analytical chemistry.
\end{abstract}

Index Terms-Academic performance, achievement, core courses, required major courses.

\section{INTRODUCTION}

Higher education provides the skilled manpower needed for socio-economic and technological development of the country. Each curriculum is designed to produce specific skilled graduate in specified area. Success in higher education is measured by academic performance or how well a student meets standards set by ministry of education and the university. How a student performs or achieves in a certain exam measured by a grade point average or grades is defined as academic performance [1]. Academic performance may depend on student, teacher, education materials, learning activities and learning atmosphere [2]-[4]. The primary goal of higher education is to produce qualified graduates. However, one of the major problem is failure in graduate education. There are number of students with a GPA below the required standard. As a result, students cannot graduate in a given period of time and lose job opportunities. Each year the number of students who are dropping out has been growing [5].Thailand has a framework for higher education that requires graduates of all levels to meet at least five learning outcomes which are moral skill, knowledge skill, intellectual skill, interpersonal relationship and

Manuscript received November 25, 2018; revised May 14, 2019. This work was supported in part by Institute for Research and Development, Suan Sunandha Rajabhat University.

The authors are with Suan Sunandha Rajabhat University, Bangkok 10300, Thailand (e-mail: naruemon.pr@ssru.ac.th, kanyarat.bu@ssru.ac.th). responsibilities skill, and numerical analysis, communication and information technology skill [6]. In order to fulfil the requirement of Thai Qualifications Framework (TQF), each course offered at a faculty must set specific and measurable course Learning Outcomes (LOs). The LOs will be shared with the students at the start of the course and this greatly benefits the students by making them aware of the new skill and knowledge that they will achieve at the end of the course. Various methods such as assignments, quizzes, tutorial, laboratory sessions and final examination were often employed by lecturers to evaluate how much the students have achieved at the end of the course. To achieve these learning outcomes, it is necessary to design courses in a curriculum for teaching and learning management. Curriculums alignment at program level is important for the quality of teaching. A curriculum design is an important mechanism that will lead to the production of qualified graduates according to the aspiration of each course [7]. Food Science and Technology is a multidisciplinary branch of science developed with vision to prepare graduates with expertise in various areas related to Food Science and Technology. Therefore, Food Science and Technology program of Suan Sunandha Rajabhat University has designed its curriculum structure consisting of 8 different courses which are general education courses, core courses, required major courses, elective major courses, professional English courses, management science courses, project and internship courses, and free elective courses to meet the requirements of TQF as shown in Fig. 1. According to our earlier study on the proportion of the variation in the academic performance from the courses achievement of Food Science and Technology students, required major courses, general education courses and elective major courses have a great influence on the academic performance than any other courses. Core courses, general education courses, required majors courses, elective major courses and management science courses are highly correlated, and these courses account for $96.7 \%$ of the variation in achievement. The highest of the proportion of variation in the academic performance is from require major courses [8].

Generally, core course subjects are designed for first three semesters to prepare the students for their further study in their required major courses. Therefore, the objective of this study is to investigate on the relationship between the academic performances in required major courses and the core courses achievement of Food Science and Technology students at Suan Sunandha Rajabhat University, Thailand. The results might be beneficial as a guideline for advising and assisting the students in a timely fashion and for improving 
curriculum leading to the production of qualified graduates with a high course achievement.

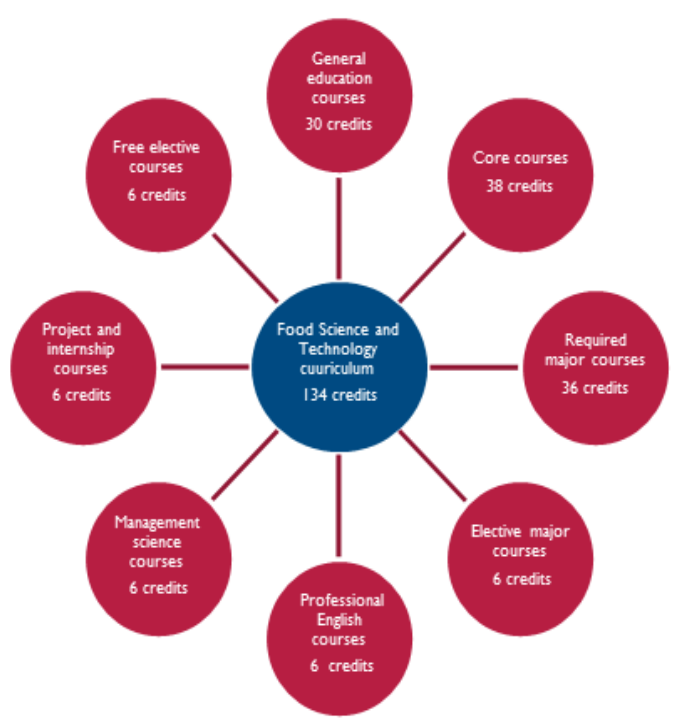

Fig. 1. Food Science and Technology curriculum structure.

\section{THE STUDY}

\section{A. Data Collection}

The objective of this paper is to construct a regression model for measuring the proportion of variation in the academic performance in required major courses form the core courses achievement of Food Science and Technology students. The online study reports of 183 graduates from Bachelor of Science in Food Science and Technology, Suan Sunandha Rajabhat University during an academic year of 2011-2017 were collected.

\section{B. Variables}

Grade of each subject in the core courses (38 credits) including Calculus 1, Calculus 2, Basic chemistry, Basic chemistry laboratory, Organic chemistry, Organic chemistry laboratory, Physical chemistry, Physical chemistry laboratory, Analytical chemistry, Analytical chemistry laboratory, Basic biology, Basic biology laboratory, Biochemistry, Biochemistry laboratory, Microbiology, Microbiology laboratory, Basic physics and Basic physics laboratory were used as independent variables while the average score level in required major courses (36 credits) including Food standard and regulations, Nutrition, Statistics and experimental design for food science and technology, Food microbiology, Food microbiology laboratory, Food plant sanitation, Food quality aspects for physical quality and sensory measurement, Food processing 1, Food processing 2, Food engineering 1, Food engineering 2, Food Chemistry, Food Analysis, Seminar in food science and technology, and food quality assurance was calculated and was being assigned as a dependent variable in regression analysis.

\section{Statistical Analysis}

Multiple linear regression was applied to construct models. Multiple linear regression is a statistical method that allows us to summarize and study relationships between several independent variables and the dependent variable and the relationship is indicated by multiple correlation coefficient (R). There is a strong relationship among the variables while the value of $R$ is close to 1.00 . In this study, the coefficient of determination or r-squared was used to determine the proportion of variation in average score level in required major courses resulting from the learning outcomes in each subject. The coefficient of determination (denoted by $R^{2}$ ) is a better indicator of strength of a relationship than the correlation coefficient. It identifies the percentage of variation of the dependent variable that is directly attributable to the variation of the independent variables [9]. The coefficient of determination including Pearson correlation and Partial correlation were also used to measure the strength and direction of relationship between the success rate of each subject and the degree of success in required major courses. Factor analysis is a statistical method that can be used for reducing a large number of variables and for investigating whether a number of variables of interest are linearly related to a small number of unobservable factors [10], [11]. Factor analysis was used to grouping independent variables that were linearly related into factors in this study.

\section{FINDINGS}

The grade point average (GPA) distribution of 183 graduates from Bachelor of Science in Food Science and technology during the academic of 2011-2017 was shown in Fig. 2. The academic performance of the graduates with GPA between 2.00-2.50, 2.51-3.0, and 3.01 were defined as low, moderate and high level respectively. The group with a low academic performance level accounted $44 \%$ of the graduates while the moderate and high level achievement accounted $32 \%$ and $24 \%$ respectively. We also found that around $20 \%$ of the graduates achieved average grade of required major courses less than 2.00 (details were not reported).

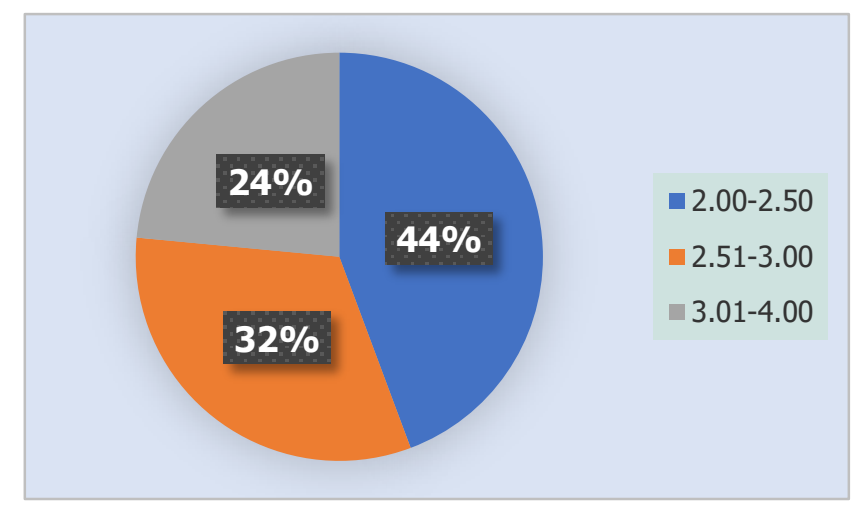

Fig. 2. Grade point average distribution of food science and technology graduates during 2011-2017.

The results of the correlation analysis between each subject grades in core courses and required major courses average grade was presented in Table I. It indicated that there was a positive significant linear relationship between the core courses achievement and the academic performance in required major courses except Basic biology laboratory. The subjects with the highest levels of relationship in the top five which presented Pearson correlation coefficient greater than 0.5 were Analytical chemistry, Physical chemistry, Organic 
chemistry, Biochemistry, and Physical chemistry laboratory respectively. Moreover, the relationship between Analytical chemistry grade and required major courses average grade was quite strong with a correlation coefficient of 0.694 . If we consider strength and direction of a linear relationship between subject grades of core courses and required major courses average grade whilst controlling the effect of other subjects indicating by partial correlation coefficient, the relationship between Analytical chemistry grade and required major courses average grade was the greatest with a partial correlation coefficient of 0.327 .

TABLE I: THE RELATIONSHIP BETWEEN SUBJECT GRADES IN CORE COURSES AND REQUIRED MAJOR COURSES AVERAGE GRADE

\begin{tabular}{|c|c|c|}
\hline Subject & $\begin{array}{l}\text { Pearson correlation } \\
\text { coefficient }\end{array}$ & $\begin{array}{l}\text { Partial correlation } \\
\text { coefficient }\end{array}$ \\
\hline Analytical chemistry & 0.694 & 0.327 \\
\hline Physical chemistry & 0.583 & 0.042 \\
\hline Organic chemistry & 0.528 & 0.085 \\
\hline $\begin{array}{l}\text { Biochemistry } \\
\text { Physical chemistry }\end{array}$ & 0.525 & 0.136 \\
\hline laboratory & 0.51 & 0.149 \\
\hline Basic biology & 0.499 & 0.221 \\
\hline $\begin{array}{l}\text { Microbiology } \\
\text { Analytical chemistry }\end{array}$ & 0.47 & 0.163 \\
\hline laboratory & 0.459 & 0.251 \\
\hline $\begin{array}{l}\text { Basic chemistry } \\
\text { Microbiology }\end{array}$ & 0.434 & -0.053 \\
\hline $\begin{array}{l}\text { laboratory } \\
\text { Basic chemistry }\end{array}$ & 0.393 & -0.009 \\
\hline $\begin{array}{l}\text { laboratory } \\
\text { Biochemistry }\end{array}$ & 0.382 & 0.051 \\
\hline laboratory & 0.363 & -0.01 \\
\hline Basic physics & 0.363 & 0.12 \\
\hline Calculus 1 & 0.335 & 0.077 \\
\hline $\begin{array}{l}\text { Calculus } 2 \\
\text { Basic physics }\end{array}$ & 0.288 & 0.036 \\
\hline $\begin{array}{l}\text { laboratory } \\
\text { Organic chemistry }\end{array}$ & 0.274 & 0.058 \\
\hline $\begin{array}{l}\text { laboratory } \\
\text { Basic biology }\end{array}$ & 0.215 & 0.031 \\
\hline laboratory & 0.099 & -0.091 \\
\hline
\end{tabular}

TABLE II: THE COMPONENT ANALYSIS OF SUBJECT IN CORE COURSES

\begin{tabular}{clc}
\hline \hline $\begin{array}{l}\text { Component } \\
\text { (Factor) }\end{array}$ & Subject & $\begin{array}{l}\% \\
\text { Variance }\end{array}$ \\
\hline 1 & $\begin{array}{l}\text { Calculus 1,Calculus 2, Basic physics, Basic } \\
\text { chemistry, Basic chemistry laboratory }\end{array}$ & 17.884 \\
2 & $\begin{array}{l}\text { Organic chemistry, Physical chemistry } \\
\text { laboratory, Analytical chemistry }\end{array}$ & 15.776 \\
3 & $\begin{array}{l}\text { Analytical chemistry laboratory, } \\
\text { Biochemistry, Biochemistry laboratory }\end{array}$ & 14.794 \\
4 & $\begin{array}{l}\text { Basic biology, Physical chemistry, Organic } \\
\text { chemistry laboratory , Microbiology }\end{array}$ & 11.064 \\
5 & $\begin{array}{l}\text { Microbiology laboratory, Basic physics } \\
\text { laboratory, Basic biology laboratory }\end{array}$ & 9.50 \\
\hline \hline
\end{tabular}

Since there were simple correlations between each pair of independent variables, grouping of variables were performed by factor analysis. There are five components that were extracted from 18 subject grades. The result of component analysis was presented in Table II. It revealed that factor 1 factor 2 , factor 3 , factor 4 and factor 5 can explain $17.884 \%$, $15.776 \%, 14.794 \%, 11.064 \%$ and $9.50 \%$ of the sum of all observed variances respectively. Overall, the five factors explain $69.019 \%$ of the sum of all observed variances.

The multiple regression model was conducted using the factor scores and the factor scores were calculated using equation (1) - (5).

Factor score $1=0.883 \times($ calculus1grade $)$

$$
\begin{aligned}
& +0.768 \times(\text { calculus } 2 \text { grade }) \\
& +0.663 \times(\text { basic physics grade }) \\
& +0.589 \times(\text { basic chemistry grade }) \\
& +0.419 \times(\text { basic chemistry laboratory grade })
\end{aligned}
$$

Factor score $2=0.792 \times($ physical chemistry laboratory grade $)$

$$
\begin{aligned}
& +0.771 \times(\text { analytical chemistry grade }) \\
& +0.711 \times(\text { orannic chemistry grade })
\end{aligned}
$$

Factor score $3=0.844 \times($ biochemistry laboratory grade $)$

$$
\begin{aligned}
& +0.745 \times(\text { biochemistry grade }) \\
& +0.565 \times(\text { analytical chemistry laboratory grade })
\end{aligned}
$$

Factor score $4=0.755 \times($ microbio $\log \mathrm{y}$ grade $)$

$$
\begin{aligned}
& -0.630 \times(\text { organic chemistry laboratory grade }) \\
& +0.584 \times(\text { physical chemistry grade }) \\
& +0.505 \times(\text { basic bio } \log y \text { grade })
\end{aligned}
$$

$$
\text { Factor score } \begin{aligned}
5= & 0.850 \times(\text { basic physics aboratory grade }) \\
& -0.647 \times(\text { basic bio } \log \text { y laboratory grade }) \\
& +0.535 \times(\text { microbiolog y laboratory grade })
\end{aligned}
$$

The multiple regression model is given by equation (6). It is significant with $r_{\text {adj }}^{2}=0.626$ Durbin $=1.504$, Standard Residual=3.585 and P-value for normality of the error distribution $=0.026$.

$$
\begin{aligned}
& \text { Average score required major courses }=2.483+0.328 \times(\text { factor score } 2) \\
& +0.202 \times(\text { factor score } 3) \\
& +0.151 \times(\text { factor score } 1) \\
& +0.150 \times(\text { factor score } 4) \\
& +0.064 \times(\text { factor score } 5)
\end{aligned}
$$

From Table III, the proportion of the variation of factor score 1, 2, 3, 4 and 5 whilst controlling the effect of other factor scores are $0.409,0.698,0.515,0.406$ and 0.186 respectively.

The results indicated that the relationship between factor score 2 and average grade of required major courses are strongest while the relationship between factor score 5 and average grade of required major courses are weakest. Therefore, we can conclude that subject achievement in Organic chemistry, Physical chemistry laboratory and Analytical chemistry in factor 2 component highly affected the average grade of required major courses. 
TABLE III: PROPORTION OF THE VARIATION OF FACTOR SCORES WHILST CONTROLLING THE EFFECT OF OTHER FACTORS

\begin{tabular}{cc}
\hline \hline Component (Factor) & Proportion of the variation \\
\hline 1 & 0.409 \\
2 & 0.698 \\
3 & 0.515 \\
4 & 0.406 \\
5 & 0.186 \\
\hline \hline
\end{tabular}

\section{CONCLUSIONS}

The findings of this study indicate that there are positive significant relationship between all subjects in core courses and the average grade in required major courses. Grade of subjects in core courses has relationship and can be divided into five groups. The learning outcomes of the subjects in each group are coherent. Organic chemistry, Physical chemistry laboratory and Analytical chemistry subjects have a great influence on required major courses learning than any other courses. The multiple regression model indicates that all grades of subjects in core courses account for about $63 \%$ of the variation in required major courses achievement. Since previous study had revealed that require major courses accounted the highest of the proportion of variation in the academic performance, therefore, we can use this model to predict average grade in required major courses from all grades of subject in core courses to investigate on the students who are likely to fail in their education success for early assistance, for extinction rate decrease, and for academic achievement level increase as well. Curriculum organization or the subjects alignment is crucial for optimizing students learning and academic success. The findings can be beneficial for a new curriculum development or a major revision of Food Science and Technology curriculum.

\section{ACKNOWLEDGMENT}

The authors wish to acknowledge their grateful appreciation for the financial subsidy provided by Suan Sunandha Rajabhat University.

\section{REFERENCES}

[1] T. York, C. Gibson, and S. Rankin, "Defining and measuring academic success," Practical Assessment, Research \& Evaluation, A Peer-reviewed Electronic Journal, vol. 20, no. 5, pp. 1-20, 2015.

[2] I. Mushtaq and S. Khan, "Factors affecting students' academic proformance," Global Jouranl of Management and Business Research, vol. 12, pp. 16-22, 2012.

[3] K. Bussaban and N. Prapasuwannakul, "Probability model for predicting different level of academic success in students of faculty of science and technology," Turkish Online Journal of Educational Technology; Special Issue for INTE 2016, pp. 264-267, December 2016.

[4] S. Vinijlul, "Relationship between academic admission scores and academic achievement of students of Kuakarun Faclty of Nursing Navamindradhiraj University," Kuakarun Journal of Nursing, pp. 94-107, vol. 21, December 2014.

[5] P. Cheewaprakobkit, "Study of factors analysis affecting academic achievement of undergraduate students in international program," in Proc. the International Multi Conference of Engineers and Computer Scientists, March 13-15, 2013, Hong Kong.
[6] The Higher Education Commission. National Qualifications Framework for Higher Education in Thailand: Implementation Handbook. [Online]. Available: http://www.mua.go.th/users/tqf-hed/news/FilesNews/FilesNews8/NQ F-HEd.pdf

[7] J. Biggs and C. Tang, Teaching for Quality Learning at University, New York, NY: Society for Research into Higher Education \& Open University Press, 2007.

[8] N. Prapasuwannakul and K. Bussaban, "The proportion of the variation in the academic performance form the courses achievement of food science and technology students," in Proc. Book of International Conference on New Horizons in Education, pp. 864-867, vol. 3, November 2017.

[9] G. Keller, Staistics for Management and Economics Abbreviated (7th ed), Thson South-Western, China, 2007.

[10] B. Williams, A. Onsman, and T. Brown, "Exploratory factor analysis: A five-step guide for novices," Journal of Emergency Primary Health Care (JEPHC), Article 990399, vol. 8, issue 3, 2010.

[11] P. Tryfos, Business Statistics, McGraw-Hill Inc.US, 1989, ch 14.

Copyright (C) 2019 by the authors. This is an open access article distributed under the Creative Commons Attribution License which permits unrestricted use, distribution, and reproduction in any medium, provided the original work is properly cited (CC BY 4.0).

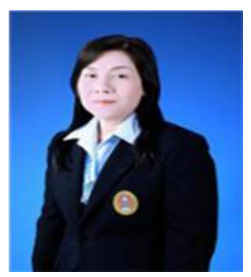

Naruemon Prapasuwannakul got a bachelor of science (BSc) in microbiology from Chulalongkorn University, Bangkok, Thailand in 1981 and a master of applied science (MAppSc) in food engineering from University of New South Wales, Sydney, Australia in 1989.

She has been working as a lecturer at the Department of Food Science and Technology, Suan Sunandha Rajabhat University, Bangkok, Thailand since 1998. Her previous publications are:

1. N. Prapasuwannakul and M. Panbualuang, "Evaluation of thermal processing for reduction of Salmonella spp. and Escherichia coli in pork sausage wrapped in banana leaves," presented at the Conference of International of Arts and Sciences, Toronto, Canada, June 5-8, 2017.

2. Prapasuwannakul, N. and Bussaban, K., "The proportion of the variation in the academic performance form the courses achievement of Food Science and Technology students," Proceedings book of International Conference on New Horizons in Education, ed. Aytekin İŞMAN \& Ahmet ESKİCUMALI, pp. 864-867, vol.3, November 2017.

3. Bussaban K., Prapasuwannakul., "Probability Model for Predicting Different Level of Academic Success in Students of Faculty of science and Technology" Turkish Online Journal of Educational Technology (Special Issue, Dec. 2016), PP. 264-267, (2016).

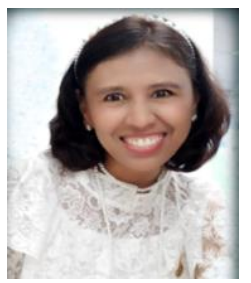

Kanyarat Bussaban was born in Nakhon $\mathrm{S}$ Thammarat, Thailand on January 28, 1970. She received her BSc degree in mathematics education, 1992 from Suan Sunandha Teacher College and M.S.in statistics, 1997 from Kasetsart University Bangkok, Thailand.

She has been working as a lecturer at the Department of Informatics Mathematics, Suan Sunandha Rajabhat University, Bangkok, Thailand since 1998. Her previous publications are as follows:

1. Bussaban K., Chumee J., From Coconut Husk Waste to Community Business, Advances in Intelligent Systems and Computing, Volume 783 (2019), pp. 229-238.

2. Bussaban K., Prapasuwannakul., "Probability Model for Predicting Different Level of Academic Success in Students of Faculty of science and Technology" Turkish Online Journal of Educational Technology (Special Issue, Dec. 2016), PP. 264-267,(2016).

3. Bussaban K., Waraporn P., "Preparing undergraduate students majoring in Computer Science and Mathematics with Data Science perspectives and awareness in the age of Big Data" Procedia- Social and Behavioral Sciences Vol:197, pp.1443-1446, (2015). 